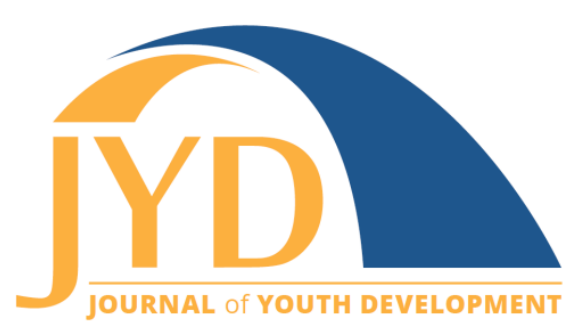

http://jyd.pitt.edu/ | Vol. 15 Issue 6 DOI 10.5195/jyd.2020.859 | ISSN 2325-4017 (online)

\title{
Critical Positive Youth Development: A Framework for Centering Critical Consciousness
}

\author{
Maru Gonzalez \\ North Carolina State University, Agricultural and Human Sciences \\ mgonza22@ncsu.edu
}

Michael Kokozos

University of Miami, Teaching and Learning

mxk1559@miami.edu

\section{Christy M. Byrd}

North Carolina State University, Teacher Education and Learning Sciences

cmbyrd3@ncsu.edu

\section{Katherine E. McKee}

North Carolina State University, Agricultural and Human Sciences

katie_mckee@ncsu.edu

\begin{abstract}
While positive youth development (PYD) has proven beneficial in developing youth's strengths, fomenting youth-adult partnerships, and cultivating leadership, missing from the framework is a critical understanding of the role and impact of power, privilege, and oppression on young people's development and lived experiences. To address this absence, we developed a critical positive youth development (CPYD) framework. Bridging positive youth development (PYD) with critical theory, CPYD positions critical consciousness - consisting of critical reflection, political efficacy, and critical action-as the th C of PYD and as integral to both the learning process and healthy socioemotional development. This paper introduces the CPYD framework and examines implications and applications for practitioners, including exploring the role of storytelling as an effective method through which to apply CPYD and highlighting one specific example.
\end{abstract}

Key words: positive youth development, critical consciousness, storytelling, Five Cs, critical theory

(cc) EY New articles in this journal are licensed under a Creative Commons Attribution 4.0 License. This journal is published by the University Library System, University of Pittsburgh and is cosponsored by the University of Pittsburgh Press. The Journal of Youth Development is the official peer-reviewed publication of the National Association of Extension 4-H Youth Development Professionals and the National AfterSchool Association. 


\section{Critical Positive Youth Development}

\section{Introduction}

In recent years, marginalized youth in the United States have experienced a rise in discrimination and bias-motivated violence. According to Federal Bureau of Investigation statistics (2017), school-based hate crimes in the United States have increased by $25 \%$ for the second consecutive year. In addition, lesbian, gay, bisexual, transgender, and queer (LGBTQ+) youth continue to navigate hostile school environments (Gonzalez, 2017; Kosciw et al., 2018) and are more likely to experience homelessness than their heterosexual, cisgender counterparts (Morton et al., 2018). Further, students of color and those with disabilities are disproportionately pushed out of school and into the criminal justice system, a phenomenon known as the school-to-prison pipeline (Brobbey, 2018; Mallett, 2016; McNeal, 2016; Russell et al., 2014). On the question of outcomes, the research is clear: the cumulative trauma of oppression-whether through violence, marginalization, or systemic inequity-results in high incidences of stress, depression, anxiety, and drug abuse (Green, 2007; Lehavot \& Simoni, 2011; Williams \& Mohammed, 2009).

Research has also demonstrated, unequivocally, that young people across all social identity groups thrive when they are connected to their schools and communities, when they have supportive adults in their lives, and when they feel empowered to leverage their voices to motivate social change (Search Institute, 2018). An emphasis on developing young people's strengths is central to positive youth development (PYD), a preeminent and widely-used model aimed at promoting the strengths of youth through supportive contexts and providing opportunities for socioemotional development (Damon, 2004; Larson, 2000; Lerner et al., 2005). Yet, despite its documented benefits, absent from PYD's traditional approach is an articulation of the impact of power, privilege, and oppression on young people's lived experiences. Such understanding should be foundational to all current youth development models given the complex challenges faced by today's young people.

Indeed, a rise in bias-based bullying coupled with an increasingly diverse population (Vespa et al., 2018), a growing public awareness of systemic inequity, and a rising interest in youth organizing and activism-including and especially among marginalized young people (Braxton, 2016) -necessitates a critical approach to PYD. Further, scholars in the area of youth development have called for social justice principles and critical theory to play a more prominent role in youth development generally (Ginwright \& Cammarota, 2002; Sherrod et al., 2006; Travis \& Leech, 2014) and within PYD-informed programs specifically (Case, 2017; ImaniFields et al., 2018; McDaniel, 2017; Tyler et al., 2019). In order to foster greater conceptual 


\section{Critical Positive Youth Development}

clarity and understanding about how to bridge critical theory and PYD, we propose a critical positive youth development (CPYD) framework for broad use in both schools and youth-serving organizations.

This paper first reviews literature related to PYD-specifically examining the Five Cs of PYD (Lerner et al., 2005)-and critical theory, focusing more narrowly on critical consciousness in general and as applied to PYD specifically. We then introduce a CPYD framework. Finally, we discuss CPYD applications and implications for practice, including examining storytelling as an effective method through which to apply CPYD and highlighting one specific example.

\section{Positive Youth Development: Benefits and Limitations}

Throughout modern history, young people have played an integral role in advancing civil rights and moving the needle on a variety of social justice issues. From child labor strikes, education reform, and voting rights to the more recent Black Lives Matter movement, March for Our Lives, and the School Climate Strikes, young people have consistently been on the frontlines of fostering a more compassionate and inclusive world. Despite their contributions, however, young people continue to be regarded as either naively idealistic on the one hand or grossly uninformed and indifferent on the other (Gonzalez \& Kokozos, 2016). Biases against workingclass youth of color run even deeper, as they are often deemed violent, dangerous, and unworthy of help and frequently used as scapegoats to decry societal issues like gang violence, teen pregnancy, and drug abuse (Warren \& Kupscznk, 2016).

Yet, contrary to dominant narratives about youth engagement, young people have a vested interest in addressing complex sociopolitical issues to ensure an equitable future for their generation and generations to follow. Scholarship, particularly in the area of PYD, demonstrates that youth thrive when they feel empowered to leverage their voices to motivate social change (Lerner et al., 2005; Search Institute, 2018). PYD is a strengths-based approach to adolescent development, which seeks to assist young people in reaching their full potential (Damon, 2004; Larson, 2000). Built on the premise that engaged and empowered young people become engaged and empowered adults (Zaff et al., 2011), PYD frameworks came about as an alternative to interventions that positioned youth in the context of risks.

Models of PYD share the goal of promoting youth thriving by nurturing young people's strengths and cultivating supportive relationships within familial, school, and peer contexts (Damon, 


\section{Critical Positive Youth Development}

2004). One such model is the Five Cs of PYD. Lerner and colleagues (2005) theorized that PYD consists of five indicators of positive youth development: (a) competence: the capacity to effectively navigate school, work, and social interactions; (b) confidence: a sense of self-worth and self-efficacy; (c) connection: positive relationships with individuals in one's environments; (d) character: a set of ethics, a regard for rules, and personal integrity; and (e) caring: empathy and sympathy for others. The Five Cs, in turn, lead to a sixth $\mathrm{C}$, contribution, which includes one's actions to improve their own well-being and that of their community.

Exemplified by the Five Cs model, PYD provides an effective framework for cultivating developmental assets that reduce risk behaviors and promote youth strengths (Benson et al., 2011; Search Institute, 2018). Yet despite its benefits, PYD fails to consider the role of privilege, power, and oppression in young people's lives (McDaniel, 2017). Further, PYD does not provide youth with the knowledge and skills to competently challenge systemic oppression so that they may contribute to the well-being of all people in their communities. Developing young people's critical consciousness using a critical theoretical lens will help to ensure PYD serves all youth in a manner that is equitable, socially just, and culturally responsive.

\section{Centering Critical Consciousness in PYD}

Critical theory provides a lens through which to consider privilege and power in youth development. Broadly defined, critical theory seeks to understand and address the societal structures that create and reinforce social, economic, and political inequities (Friere, 2000; Giroux, 1981; hooks, 1994). In contrast to initiatives aimed at diversity and inclusion which tend to focus exclusively on recognizing and celebrating social group differences, critical pedagogues and theorists examine how said differences perpetuate oppression across individual, institutional, and social/cultural levels. Critical theory's multi-level analysis of the dynamics of privilege and oppression is balanced by attention to opportunities for intervention and social change (Bell, 2007).

In the classroom and within youth-serving organizations, critical educators aim to empower youth to understand their personal experiences within an unequal social system that grants systemic privileges or disadvantages to individuals based on social group memberships (Bell, 2007; Love, 2000). Simultaneously, critical theory encourages individual and collective action within and across social identity groups-including collaborative partnerships between youth and adults—to change the systems that perpetuate injustice (Freire, 1970/2000; Ginwright \& 


\section{Critical Positive Youth Development}

Cammarota, 2002; Giroux, 1981). Critical theory also emphasizes self-reflection (Habermas, 1991; Huerta-Charles, 2007) and calls upon adults and youth to examine their multiple social identities and understand the ways in which they intersect and inform one another within classrooms, youth-serving organizations, and broader communities (Crenshaw, 1989).

\section{Critical Consciousness}

Once young people begin to develop a critical understanding of privilege, oppression, social location, and the historic origins of structural inequality, they learn how to challenge injustice and move toward social change (Harro, 2010; Love, 2000). The ability for individuals to identify and reflect upon oppressive social conditions-particularly as they relate to one's positionalityand subsequently take action to change said conditions is what Brazilian educator Paolo Friere $(1973,2000)$ initially conceptualized as critical consciousness, a centerpiece of critical theory. Friere viewed the relationship between reflection and action as a reciprocal and dynamic process, whereby reflection leads to informed action, which subsequently strengthens reflection.

Building upon Freire's $(1973,1970 / 2000)$ seminal work on critical consciousness, developmental scholars have proposed political efficacy-an individual's belief in their capacity to effectively enact social change-as necessary for transforming reflection to action (Watts et al., 2011). This expanded conceptualization of critical consciousness consists of three overarching and interconnected components. The first component, critical reflection, refers to critically understanding the ways in which systems of power create and sustain oppression. Critical reflection can be thought of as the end of a continuum anchored by system justification beliefs (Watts et al., 2011). According to system justification theory, individuals are motivated to assume that the status quo is fair and legitimate in order to perceive their lives as predictable and within their control (Jost \& Andrews, 2011). Thus, individuals with system-justifying beliefs see inequality in society as the result of individual failings or fate, instead of acknowledging how institutions are responsible for individuals' circumstances, as is the case with critical reflection. The second component, political efficacy, is the belief in one's capacity to change oppressive social conditions. Critical reflection and political efficacy are key to the development of critical action, the third component of critical consciousness. The critical action component denotes individual and collective action-including activism and advocacy-that challenges unjust and oppressive practices and policies with the ultimate aim of social transformation (Diemer \& Rapa, 2016). 


\section{Critical Positive Youth Development}

Recently, a growing number of youth development scholars have examined the ways in which critical consciousness can yield positive developmental outcomes, including clearer vocational aspirations (McWhirter \& McWhirter, 2016; Olle \& Fouad, 2015), improved socioemotional wellbeing (Christens \& Peterson, 2012), empowerment (Ballard \& Ozer, 2016; Christens et al., 2016; Watts et al., 2011), academic achievement (Seider et al., 2020), and occupational success (Diemer \& Blustein, 2006; Diemer et al., 2010). Further, studies have demonstrated a positive association between critical consciousness and contextual factors, such as classrooms that value diversity of thought (Godfrey \& Grayman, 2014) and parent and peer socialization related to issues of injustice and oppression (Bañales et al., 2020; Diemer, 2012).

Among marginalized youth, research has found that critical consciousness-specifically critical reflection-assists in addressing feelings of powerlessness and internalized oppression by challenging dominant, often stigmatizing narratives, and the systems of power through which they are perpetuated (Watts et al., 2011). Furthermore, scholars have noted that community engagement for people of color is often inextricably linked to critical action; therefore, efforts to address systematic inequality can serve as an important coping mechanism (Hope \& Spencer, 2017).

Yet, while critical consciousness literature has historically concentrated on youth of color and those from low socioeconomic backgrounds, research has found that critical consciousness benefits the civic development of all young people-including those with privileged identitiesand facilitates perspective-taking and learning across differences (Godfrey \& Grayman, 2014; Love, 2000; Tyler et al., 2019). Indeed, the capacity to understand and analyze power, privilege, and oppression is also key for ally development and accountability (Love, 2000). Given the lack of focus on privileged and intersectional identities in critical consciousness scholarship, we turned to transformative leadership-a related framework within the field of leadership education that can be more widely applied to young people across all social group memberships-in order to broaden current conceptualizations of critical consciousness in general and within the context of CPYD.

\section{Transformative Leadership}

Transformative leadership addresses questions of justice and democracy through the critique of inequitable practices and inappropriate uses of power and privilege (Shields, 2010).

Engagement in transformative leadership is grounded in critical theory and begins with critical reflection and analysis, moves to enlightened understandings, and results in action (Shields, 


\section{Critical Positive Youth Development}

2010). Transformative leadership requires radical, critical theory to address empowerment gaps-systems and assumptions that perpetuate marginalization. For youth-serving professionals, this includes actively challenging one's assumptions about young people and advocating in solidarity with them to dismantle systems of oppression (Shields, 2016).

Unlike critical consciousness, which has typically focused on youth of color and those from low socioeconomic backgrounds, transformative leadership can be developed in youth across all social identity groups. In doing so, transformative leadership fosters competencies-such as examining one's own participation in control and cultural domination-that aid in ally development (Brown, 2006; Bruce et al., 2019; Dunn, 1987; Senge, 1990; Shields, 2016). Building on critical consciousness, transformative leadership requires the development and appreciation of one's privilege and power and the deconstruction and reconstruction of dominant knowledge frameworks (Shields, 2010). Moreover, moral courage, a tenet of transformative leadership, prepares youth to become more comfortable enacting public identities as agents for change, whether as allies working with or on behalf of marginalized groups or as activists organizing others to address injustice (Bruce et al., 2019; Ganz, 2009; Trueba, 1999). A transformative leadership approach, with its wide-reaching focus on all youth, expands current conceptualizations of critical consciousness and can therefore inform the work of CPYD.

\section{Putting It All Together: Introducing Critical Positive Youth Development}

Merging PYD with critical theory, CPYD is a conceptual framework that positions critical consciousness as the seventh $C$ of PYD and is intended for use with all youth across educational and community settings. Of the various frameworks that exist within PYD, our decision to focus on the Five Cs model was threefold. First, the Five Cs model has robust empirical support as a framework for youth thriving (Lerner et al., 2005; Tyler et al., 2019). Additionally, the Five Cs model emphasizes the role of context on youth development, which is particularly useful when examining the impact of strengths-based environments and systems of oppression, an area which warrants further investigation (Godfrey \& Burson, 2018; Heberle et al., 2020). Finally, while research connecting critical consciousness to PYD remains scarce, an increasing number of scholars are examining critical consciousness as it relates specifically to the Five 5 Cs (Clonan-Roy et al., 2016; Tyler et al., 2019). 


\section{Critical Positive Youth Development}

Though the term critical positive youth development has been used once in the literature (Case, 2017) as a method for working specifically with juvenile delinquent youth, our conceptualization of critical positive youth development is distinct, both in terms of content and application. Conceptually and in practice, our CPYD approach pushes and builds upon PYD literature, bringing critical consciousness to the fore.

As illustrated in Figure 1, our model assumes that the development of the Five Cs-which we refer to in this manuscript as caring, connection, character, competence, and confidence-in a strengths-based, supportive environment paves the way for critical reflection and political efficacy. Together, these components lead to the sixth $\mathrm{C}$, contribution through critical action, which reinforces the Five Cs, critical reflection, and political efficacy. The three components of critical consciousness-critical reflection, political efficacy, and critical action-make up the seventh $\mathrm{C}$ of CPYD and are required to effectively challenge oppressive social conditions.

\section{The Five Essential Propositions of CPYD}

To further elaborate on the nuances of our framework, we introduce five essential propositions, which serve as the basis for CPYD.

\section{A Critical Lens is Key to Understanding the Impact of Power, Privilege, and Oppression on Young People's Lived Experiences, Regardless of Social Group Membership.}

CPYD applies critical perspectives to understanding youths' environments and their interactions within them. Such critical understanding includes examining the role of systems-whether marginalizing or consciousness-raising - on youth development. Consistent with transformative leadership literature (Shields, 2016), CPYD views an intersectional approach to identity as integral to comprehending how young people across all social groups-and the adults with whom they interact-critically reflect upon their own positionality and learn to address oppressive social conditions by engaging in contribution through critical action. For practitioners, a focus on positionality includes being intentional about working in solidarity with rather than for young people, listening to and valuing their ideas, and ensuring they are active participants in their own transformation (Friere, 2000; hooks, 1994).

\section{Critical Consciousness is Preceded by the Development of the Five CS.}

Our conceptual model is depicted in Figure 1. Analogous to PYD, our framework assumes that strengths-based, supportive environments aid in the development of the Five Cs: caring, connection, character, competence, and confidence. Such an environment-one that allows for 
open, respectful dialogue and a diversity of perspectives-is foundational to critical consciousness development (Friere, 1973, 1970/2000). Indeed, in order for young people to engage in complex, often emotional learning about privilege and oppression and subsequently understand their capacity to motivate change, they must feel connected to their learning community, sense being cared for, have the confidence to deem their stories and perspectives as worthy of attention, and possess the competence and character to engage in informed and ethical contribution through critical action. In this way, the Five Cs promote the development of critical consciousness by engendering spaces that foster critical reflection (Godfrey \& Grayman, 2014) and build the confidence, character, and competence that fuels political efficacy (Ballard \& Ozer, 2016; Christens et al., 2016), ultimately paving the way for contribution in the form of critical action.

\section{The Development of Critical Reflection and Political Efficacy Strengthens the Five CS.}

CPYD theorizes that youth engagement in critical reflection coupled with the development of political efficacy builds the confidence, competence, and character needed to effectively engage in social change; nurtures connection and solidarity within and across social groups; and reinforces a culture of care and support. Such a hypothesis is consistent with critical consciousness scholarship, which has found that youth development of critical reflection and political efficacy leads to improved confidence (Christens \& Peterson, 2012), increased competence to address oppressive social conditions (Ballard \& Ozer, 2016; Christens et al, 2016; Watts et al., 2011), and a caring environment that encourages and values diverse perspectives (Godfrey \& Grayman, 2014).

Critical Consciousness-as an Integrated Whole Consisting of Critical Reflection, Political Efficacy, and Critical Action-is Positioned as the Seventh C and Underpins the Entire CPYD Model, Ultimately Changing How Youth Engage in Contribution.

As demonstrated in Figure 1, youth engagement in critical reflection and political efficacy leads to contribution through critical action. Together, these components-critical reflection, political efficacy, and critical action-make up critical consciousness or the seventh C of CPYD. The traditional PYD model includes contribution as the sixth $\mathrm{C}$, positing that the development of the Five Cs creates a pathway for young people to contribute to their own well-being, their families, and their broader communities (Lerner et al., 2005). In contrast, by including critical reflection and political efficacy, CPYD leads to more transformative, critically grounded and informed youth contribution and systemic change in the form of critical action. Thus, when critical reflection and political efficacy are present-as they are in our CPYD model-the outcome is contribution through critical action; when they are not, as is the case in the traditional PYD 
model, the result is solely contribution, which we view as more limited and individualistic in its conceptualization of community action and civic engagement. That is, youth may contribute in ways that are beneficial to their community-such as volunteering or donating goods and services-but they will not possess the skills necessary to engage in critically informed and collective social change.

\section{Contribution Through Critical Action Reinforces the Five Cs, Critical Reflection, and Political} Efficacy.

Contribution through critical action, as illustrated in Figure 1, fortifies the Five Cs by fostering more supportive, affirming, empowered, and equitable environments where all young people can thrive while continuing their evolving journeys as social justice advocates. Simultaneously, youth engagement in critical action reinforces critical reflection and political efficacy, which creates a reciprocal relationship between critical action and the other components of CPYD. The development of the Five Cs, critical reflection, and political efficacy leads to the sixth $\mathrm{C}$, contribution through critical action, which in turn reinforces the Five $\mathrm{Cs}$, strengthens critical reflection, and builds political efficacy. Addressing the impact of one's environment on critical consciousness development can assist in shifting the focus from individuals to systems (Godfrey \& Grayman, 2018), including examining critical consciousness as a characteristic of consciousness-raising systems (Heberle et al., 2020). 
Figure 1. Conceptual Model of Critical Positive Youth Development

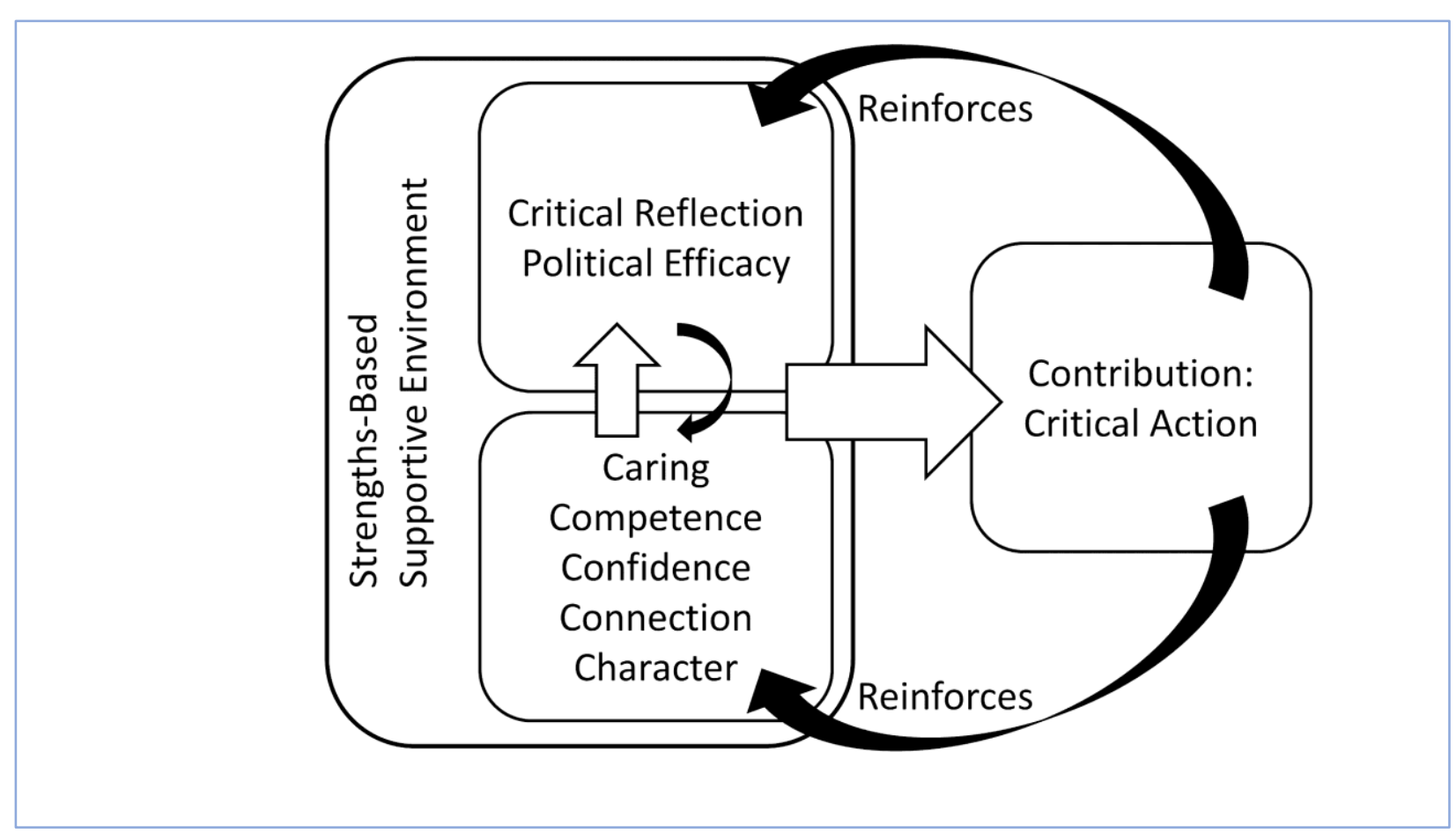

Note: The development of the Five Cs in a strengths-based, supportive environment lays the groundwork for critical reflection and political efficacy. Together, these components lead to the sixth $\mathrm{C}$, contribution through critical action, which reinforces the Five Cs, critical reflection, and political efficacy.

Simultaneously, the existence of critical reflection and political efficacy strengthens the Five Cs. The white arrows illustrate conditionality or the presumption that certain conditions must be met before other components can be developed. The black arrows serve as reinforcers. Critical consciousness-consisting of critical reflection, political efficacy, and critical action-is integrated throughout the model and makes up the seventh $\mathrm{C}$ of CPYD

\section{Applying CPYD to Storytelling}

To achieve the vision of centering critical consciousness within a PYD framework, which contributes to healthy youth development and societal change, we identified a complementary pedagogical method: storytelling. The sharing of personal stories necessitates trust and support, both of which are integrated into environments that nurture the Five Cs. In addition, storytelling is useful in promoting critical reflection, political efficacy, and ultimately contribution in the form of critical action by exposing young people to societal inequities, encouraging selfreflection, and integrating perspectives not commonly included in mainstream discourses (Bell, 2007, 2010). 


\section{Critical Positive Youth Development}

Storytelling, particularly counter-storytelling, can be used as a pedagogical tool for cultivating critical consciousness and understanding across differences (Giles \& Hughes, 2009; Solórzano \& Yosso, 2002). Solórzano and Yosso (2002) conceptualize counter-storytelling as "a method of telling the stories of those people whose experiences are not often told" (p. 32). While the sharing of personal stories, especially counter-stories, can be transformative and empowering, doing so necessitates being fully present, listening actively and intently, taking risks, honoring boundaries, and understanding one's power and privilege in order to be a partner in the learning process (Wasserman \& Doran, 1999). Such conditions are reinforced in a strengthsbased culture of caring, connection, confidence, character, and competence. The role of the adult ally or practitioner, in or out of school, thus plays a crucial role in fostering such a climate and ensuring that the process of storytelling is guided through a critical lens.

\section{Piloting CPYD: \#PassTheMicYouth}

A new and ongoing North Carolina State University Extension program that exemplifies the power of storytelling through a CPYD framework is \#PassTheMicYouth, a youth-led podcast and blog aimed at amplifying youth voices, shining a spotlight on youth activism, and providing practitioners with resources for developing critical consciousness (Gonzalez et al., 2019). Podcast episodes and blog posts feature youth activists engaging in contribution through critical action within their schools and communities, as well as the adult allies with whom they collaborate. Young people are also encouraged to submit original social justice and activismrelated pieces, which may include personal narratives, spoken word poetry, artwork, and music.

Within \#PassTheMicYouth, the six Cs of CPYD are developed as follows: caring by seeking to understand others' lived experiences and conveying an urgency for positive social change, connection by creating a supportive and trusting space and fostering meaningful bonds between and among facilitator(s) and participants, confidence by working with youth one-onone to develop their story and/or project ideas, character by tethering youth's ideas and learning to ethics and a sense of responsibility to be equitable and inclusive in both words and actions, competence by planning for and securing opportunities for young people to share their stories and ideas, and contribution through critical action by translating stories and/or projects into sustainable social change initiatives.

The seventh C, critical consciousness, underpins the entire CPYD approach. One way this takes place includes reconceptualizing \#PassTheMicYouth student creations as curricula. This reconceptualization encourages youth to (a) critically reflect upon and engage with their 


\section{Critical Positive Youth Development}

productions, (b) demonstrate how they succumb to or resist the oppressive properties that give meaning to their expressions, and (c) facilitate self- and social awareness of how marginalization and resistance are shaped by dominant narratives. Further, listening to youthcentered interviews, reading blog posts, and engaging with art give youth access to "possible selves" such that they develop the political efficacy to view themselves as capable of being allies, advocates, and activists (Richardson \& Eccles, 2007) who demonstrate contribution in the form of critical action.

To extend the dialogue generated by \#PassTheMicYouth's podcasts and blogs, educators are provided with discussion questions meant to examine the dynamics of power and unpack the sociopolitical context in which each production is situated. An example includes the premiere podcast episode, Not Your Mother's Activism, which covers the role of youth activism, social media as a tool for social change, and a poignant youth account of the Nicaraguan protests spurred in 2018 in response to the government restricting social welfare measures and restraining civil and political dissent. Discussion questions examined the role of protest across generations and explored whether violence is ever legitimate in the pursuit of social justice.

The development of critical reflection and political efficacy within \#PassTheMicYouth paves the way for the sixth $\mathrm{C}$ of CPYD, contribution through critical action. For example, \#PassTheMicYouth hosts events to encourage young people to share their work in public settings. At these events, young people demonstrate contribution in the form of critical action by creating awareness about a social issue(s) and expanding networks to build coalitions. Though \#PassTheMicYouth's program is still being piloted and a CPYD-inspired curriculum is in development, preliminary evaluations have yielded promising results. Youth participants have reported increased confidence in their capacity to motivate social change, as well as a greater awareness of power, privilege, and difference (Gonzalez et al., 2019). More research into the project to demonstrate storytelling as a mechanism for applying CPYD in educational settings is forthcoming.

\section{Implications for Practice}

CPYD recognizes the value of youth voices and the capacity of young people to challenge inequity and transform the societal structures that sustain oppression. Taking a critical perspective on PYD means practitioners view youth as participants in systems of oppression who can, with the right environmental support, challenge and transform those systems. This 


\section{Critical Positive Youth Development}

shift in perspective acknowledges that thriving does not occur only through nurturing individual strengths and relationships; youth must also recognize the systems through which they move and the motivation to contribute by engaging in critical action.

In addition to expanding young people's comprehension of systems of oppression, a CPYD approach calls on practitioners to conceptualize social identities and context more deeply. Specifically, practitioners must understand the ways in which social identities shape development and access to opportunities and recognize that context consists of oppressive structures and spaces as well as potentially consciousness-raising ones. In short, CPYD necessitates that practitioners shift from an individualistic to a systemic view of youth development.

To implement CPYD effectively, practitioners should thus be exemplars of critical consciousness. In particular, practitioners should demonstrate a willingness to engage in ongoing critical reflection in order to participate equally in the process of collective action with young people (Shields, 2010) while recognizing the ways in which their social identities may impact group dynamics. Further, practitioners should take steps to foster a trusting and bidirectional learning environment, whereby youth participants and practitioner(s) are encouraged to be both learners and teachers. Because developing critical consciousness is an ongoing and iterative process, practitioners should seek opportunities for continued professional development to best support and connect young people to resources as needed.

CPYD challenges systems of power, which may cause practitioners working within this framework-and the young people with whom they collaborate-to face pushback from colleagues, leadership, members of the community, and fellow youth participants. In order to navigate such resistance, practitioners must have the skills to effectively clarify misconceptions and respond to strong emotions, with the understanding that people are at different points of awareness as they relate to social justice. Additionally, practitioners should take steps to prioritize the physical, mental, and emotional safety of youth participants. Ensuring safety includes being trauma-informed; understanding the ethics related to privacy and confidentiality; and assessing the risks of youth speaking out in public, particularly in resistant or hostile settings. Because the work of CPYD can be challenging and elicit defensiveness, it is important to collaborate with supportive colleagues and seek the buy-in of leadership whenever possible. Any opportunity to demonstrate the efficacy and effectiveness of CPYD-including evaluating impact—will increase the chances of CPYD being embraced and institutionalized. 
Our CYPD framework builds on PYD, particularly the Five Cs model (Lerner et al., 2005), by highlighting the necessity of a critical approach to youth development. However, we argue that for youth contributions to create a more equitable and just society, youth environments must also foster critical consciousness. One way youth-serving professionals can implement CYPD is through storytelling and dialogue that deepens youth understanding of privilege and oppression, affirms youth potential for positive societal change, and motivates contribution through critical action.

\section{References}

Ballard, P. J., \& Ozer, E. (2016). The implications of youth activism for health and wellbeing. In J. O. Conner \& S. M. Rosen (Eds.), Contemporary youth activism: Advancing social justice in the United States (pp. 223-244). Praeger.

Bañales, J., Marchand, A. D., Skinner, O. D., Anyiwo, N., Rowley, S. J., \& Kurtz-Costes, B. (2020). Black adolescents' critical reflection development: Parents' racial socialization and attributions about race achievement gaps. Journal of Research on Adolescence, 30, 403-417.

Bell, L. A. (2007). Theoretical foundations for social justice education. In M. Adams, L.A. Bell \& P. Griffin (Eds.), Teaching for diversity and social justice (pp. 3-15). Routledge.

Bell, L. A. (2010). Storytelling for social justice: connecting narrative and the arts in antiracist teaching. Routledge.

Benson, P. L., Scales, P. C., \& Syvertsen, A. K. (2011). The contribution of the developmental assets framework to positive youth development theory and practice. In R. M. Lerner, J. V. Lerner, \& J. B. Benson (Eds.), Advances in child development and behavior: Positive youth development research and applications for promoting thriving in adolescence (pp. 195-228). Elsevier.

Braxton, E. (2016). Youth leadership for social justice: Past and present. In Conner, J., \& Rosen, S. (Eds.), Contemporary youth activism: Advancing social justice in the United States (pp. 25-38). Prager.

Brobbey, G. (2018). Punishing the vulnerable: Exploring suspension rates for students with learning disabilities. Intervention in School and Clinic, 53, 216-219. https://doi.org/10.1177/1053451217712953

Brown, K. M. (2006). Leadership for social justice and equity: Evaluating a transformative framework and andragogy. Educational Administration Quarterly, 42(5), 700-745. https://doi.org/10.1177/0013161X06290650 
Bruce, J., McKee, K., Morgan-Fleming, J., Warner, W.J. (2019). The Oaks Leadership Scholars: Transformative leadership in action. International Journal of Teaching and Learning in Higher Education, 31(3), 536-546. http://www.isetl.org/ijtlhe/pdf/IJTLHE3574.pdf

Case, A. D. (2017). A critical-positive youth development model for intervening with minority youth at risk for delinquency. American Journal of Orthopsychiatry, 87(5), 510-519. https://doi.org/10.1037/ort0000273

Christens, B. D., \& Peterson, A. N. (2012). The role of empowerment in youth development: A study of sociopolitical control as mediator of ecological systems' influence on developmental outcomes. Journal of Youth and Adolescence, 41, 623-645.

Christens, B. D., Winn, L. T., \& Duke, A. M. (2016). Empowerment and critical consciousness: A conceptual cross-fertilization. Adolescent Research Review, 1, 15-27,

\section{https://doi.org/10.1007/s40894-015-0019-3}

Clonan-Roy, K., Jacobs, C. E., \& Nakkula, M. J. (2016). Towards a model of positive youth development specific to girls of color: Perspectives on development, resilience, and empowerment. Gender Issues, 33, 96-121. http://dx.doi.org/10.1007/s12147-016-9156-7

Crenshaw K. (1989). Demarginalizing the intersection of race and sex: A Black feminist critique of antidiscrimination doctrine, feminist theory, and antiracist politics. The University of Chicago Legal Forum, 1989(1),139-167. https://chicagounbound.uchicago.edu/cgi/viewcontent.cgi?article=1052\&context=uclf

Damon, W. (2004). What is positive youth development? The Annals of the American Academy of Political and Social Science, 591, 13-24. https://doi.org/10.1177/0002716203260092

Diemer, M. A. (2012). Fostering marginalized youths' political participation: Longitudinal roles of parental political socialization and youth sociopolitical development. American Journal of Community Psychology, 50, 246-256. http://dx.doi.org/10.1007/s10464-012-9495-9

Diemer, M. A., \& Blustein, D. L. (2006). Critical consciousness and career development among urban youth. Journal of Vocational Behavior, 68(2), 220-232.

Diemer, M. A., \& Rapa, L. J. (2016). Unraveling the complexity of critical consciousness, political efficacy, and political action among marginalized adolescents. Child Development, 87, 221-238.

\section{http://dx.doi.org/10.1111/cdev.12446}

Diemer, M. A., Wang, Q., Moore, T., Gregory, S. R., Hatcher, K. M., \& Voight, A. M. (2010). Sociopolitical development, work salience, and vocational expectations among low socioeconomic status African American, Latin American, and Asian American youth. Developmental Psychology, 46(3), 619-635.

Dunn, J. M. (1987). Personal beliefs and public policy. F. S. Bolin \& J. M. Falk (Eds.), Teacher Renewal: Professional Issues, Personal Choices, Teachers College Press. 
Federal Bureau of Investigation (2018). 2017 Hate crimes statistics. https://ucr.fbi.gov/hate-crime/2017

Friere, P. (1973). Education for critical consciousness. Continuum International Publishing Group.

Freire, P. (2000). Pedagogy of the oppressed (30 ${ }^{\text {th }}$ Anniversary Edition). Continuum International Publishing Group. (Original work published 1970.)

Ganz, M. (2009). Organizing Obama: Campaign, organization, movement. Proceedings of the American Sociological Association Annual Meeting, San Francisco, CA.

Giles, M. S., \& Hughes, R. L. (2009). CRiT walking race, place, and space in the academy. International Journal of Qualitative Studies in Education, 22(6), 687-696. https://doi.org/10.1080/09518390903333939

Ginwright, S.\& Cammarota, J. (2002). New terrain in youth development: The promise of a social justice approach. Social justice, 29(4), 82-95.

Giroux, H. (1981). Ideology, culture, and the process of schooling. Bergin \& Garvey.

Godfrey, E. B., \& Burson, E. (2018). Interrogating the intersections: How intersectional perspectives can inform developmental scholarship on critical consciousness. New directions for child and adolescent development, 161, 17-38.

Godfrey, E. B., \& Grayman, J. K. (2014). Teaching citizens: The role of open classroom climate in fostering critical consciousness among youth. Journal of Youth and Adolescence, 43, 1801-1817. http://dx.doi.org/10.1007/s10964-013-0084-5

Gonzalez, M. (2017). Advocacy for and with LGBT students: An examination of high school counselor experiences. Professional School Counseling, 20(1a), 38-46. http://doi.org/10.5330/1096-2409$\underline{20.1 a .38}$

Gonzalez, M., \& Kokozos, M. (2016, July 26). When it comes to social justice, adults need to \#PassTheMic. Huffington Post. https://www.huffpost.com/entry/when-it-comes-to-socialj b 11078246

Gonzalez, M., McKee, K. E., Kokozos, M., Shealy, L., \& Chan, S. (2019). \#PassTheMicYouth multimedia program: Setting the stage to amplify youth voices. Journal of Extension, 57(6). https://joe.org/joe/2019december/tt2.php

Green, R. J. (2007). Gay and lesbian couples in therapy: A social justice perspective. In E. Aldarondo (Ed.), Advancing social justice through clinical practice. Routledge, Taylor \& Francis Group.

Habermas, J. (1991). The structural transformation of the public sphere: An inquiry into a category of bourgeois society (T. Burger, Trans.). MIT press.

Harro, B. (2010). Cycle of liberation. In M. Adams, W. J. Blumenfeld, R. Casteñeda, H. Hackman, M. Peters, \& X. Zúñiga (Eds.), Readings for diversity and social justice. ( $2^{\text {nd }}$ ed., pp.52-58). Routledge. 
Heberle, A. E., Rapa, L. J., \& Farago, F. (2020, April 9). Critical consciousness in children and adolescents: A systematic review, critical assessment, and recommendations for future research. Psychological Bulletin. Advance online publication. http://dx.doi.org/10.1037/bul0000230

hooks, b. (1994). Teaching to transgress. Routledge.

Hope, E. C., \& Spencer, M. B. (2017). Civic engagement as an adaptive coping response to conditions of inequality: An application of phenomenological variant of ecological systems theory (PVEST). In Handbook on positive development of minority children and youth (pp. 421-435). Springer.

Huerta-Charles, L. (2007). Pedagogy of testimony: Reflections on the pedagogy of critical pedagogy. In P. McLaren \& J. Kincheloe (Eds.), Critical pedagogy: Where are we now? (pp. 249-262). Peter Lang.

Imani-Fields, N., Moncloa, F., \& Smith, C. (2018). 4-H social justice youth development: A guide for youth development professionals. https://docs.wixstatic.com/ugd/dd590a 72a1bbcd26ae4b44ba8a5877bb40370b.pdf

Jost, J. T., \& Andrews, R. (2011). System Justification Theory. In D. J. Christie (Ed.), The encyclopedia of peace psychology (p. wbepp273). Blackwell Publishing Ltd.

https://doi.org/10.1002/9780470672532.wbepp273

Kosciw, J. G., Greytak, E. A., Zongrone, A. D., Clark, C. M., \& Truong, N. L. (2018). The 2017 national school climate survey: The experiences of lesbian, gay, bisexual, transgender, and queer youth in our nation's schools. GLSEN.

Larson, R. (2000). Toward a psychology of positive youth development. American Psychologist, 55, 170183. https://doi.org/10.1037/0003-066X.55.1.170

Lehavot, K., \& Simoni, J. (2011). The impact of minority stress on mental health and substance abuse among sexual minority women. Journal of Consulting \& Clinical Psychology, 79: 159-170. https://doi.org/10.1037/a0022839

Lerner, R. M., Lerner, J. V., Almerigi, J., Theokas, C., Phelps, E., Gestsdóttir, S. Naudeau, S., Jelicic, H., Alberts, A. E., Ma, L., Smith, L. M., Bobek, D. L., Richman-Raphael, D., Simpson, I., Christiansen, E. D., \& von Eye, A. (2005). Positive youth development, participation in community youth development programs, and community contributions of fifth-grade adolescents: Findings from the first wave of the 4-H Study of Positive Youth Development. Journal of Early Adolescence, 25(1), 17-71.

Love, B. J. (2000). Developing a liberatory consciousness. In M. Adams, W. J. Blumenfeld, C. R., Casteneda, H. W. Hackman, M. L. Peters, \& X. Zúñiga (Eds.), Readings for diversity and social justice (pp. 599-604). Routledge.

Mallett, C. (2016). The school-to-prison pipeline: A critical review of the punitive paradigm shift. Child \& Adolescent Social Work Journal, 33(1), 15-24. https://doi.org/10.1007/s10560-015-0397-1 
McDaniel, M. (2017). Social justice youth work: Actualizing youth rights. Journal of Youth Development, 12(1), 136-148. https://doi.org/10.5195/jyd.2017.488

McNeal, L. R. (2016). Managing our blind spot: The role of bias in the school-to-prison pipeline. Arizona State Law Journal, 48, 285-311.

McWhirter, E. H., \& McWhirter, B. T. (2016). Critical consciousness and vocational development among Latina/o high school youth: Initial development and testing of a measure. Journal of Career Assessment, 24, 543-558. http://dx.doi.org/10.1177/1069072715599535

Morton, M. H., Dworsky, A., Samuels, G. M., \& Patel, S. (2018). Missed opportunities: Youth homelessness in rural America. Chapin Hall at the University of Chicago.

Olle, C. D., \& Fouad, N. A. (2015). Parental support, critical consciousness, and agency in career decision making for urban students. Journal of Career Assessment, 23, 533-544.

\section{http://dx.doi.org/10.1177/1069072714553074}

Richardson, P. W., \& Eccles, J. S. (2007). Rewards of reading: Toward the development of possible selves and identities. International Journal of Educational Research, 46(6), 341-356.

https://doi.org/10.1016/j.ijer.2007.06.002

Russell J. S, Arredondo, I., \& Williams, N. T. (2014) More than a metaphor: The contribution of exclusionary discipline to a school-to-prison pipeline, Equity \& Excellence in Education, 474), 546-564. https://doi.org/10.1080/10665684.2014.958965

Search Institute, 2018. Developmental assets among U.S. youth: 2018 update. Author.

Seider, S., Clark, S., \& Graves, D. (2020). The development of critical consciousness and its relation to academic achievement in adolescents of color. Child Development, 91(2), 451-474.

https://doi.org/10.1111/cdev.13262

Senge, P. M. (1990). The fifth discipline: The art \& practice of the learning organization. Doubleday Business.

Sherrod, L. R., Flanagan, C. A., Kassimir, R., \& Syvertsen, A. K. (Eds.). (2006). Youth activism: An international encyclopedia. Greenwood Publishing.

Shields, C. M. (2010). Transformative leadership: Working for equity in diverse contexts. Educational Administration Quarterly, 46(4), 558-589.

Shields, C. M. (2016). Transformative leadership primer. Peter Lang.

Solórzano, D. G., \& Yosso, T. J. (2002). Critical race methodology: Counter-storytelling as an analytical framework for educational research. Qualitative Inquiry, $8(1), 23-44$.

Travis, R., Jr., \& Leech, T. G. J. (2014). Empowerment-based positive youth development: A new understanding of healthy development for African American youth. Journal of Research on Adolescence, 24, 93-116. https://doi.org/10.1111/jora.12062

Trurba, H. T. (1999). Latinos unidos: From cultural diversity to politics of solidarity. Rowman \& Littlefield. 
Journal of Youth Development | http://jyd.pitt.edu/ | Vol. 15 Issue 6 DOI 10.5195/jyd.2020.859 Critical Positive Youth Development

Tyler, C. P., Geldhof, J., Black, K. L., Bowers, E.P. (2019). Critical reflection and positive youth development among white and black adolescents: Is understanding inequality connected to thriving? Journal of Youth and Adolescence, 49, 757-771. https://doi.org/10.1007/s10964-01901092-1

Vespa, J., Armstrong, D. M., \& Medina, L. (2018). Demographic turning points for the United States: Population projections for 2020 to 2060. (Current Population Reports, P25-1144.) U.S. Census Bureau.

Warren, M. R., \& Kupscznk, L. A. (2016). The emergence of a youth justice movement in the United States. In Conner, J., \& Rosen, S. (Eds.), Contemporary youth activism: Advancing social justice in the United States (pp. 39-58).Prager.

Wasserman, I., \& Doran, R. (1999). Creating inclusive learning communities. In A. L. Cooke, M. Brazzel, A. S. Craig, \& B. Greig (Eds.), Reading book for human relations training ( $8^{\text {th }}$ ed., pp. 307-310). NTL Institute.

Watts, R. J., Diemer, M. A., \& Voight, A. M. (2011). Critical consciousness: Current status \& future directions. In C. A. Flanagan \& B. D. Christens (Eds.), Youth civic development: Work the cutting edge. New Directions for Child \& Adolescent Development, 134, 43-57. https://doi.org/10.1002/cd.310

Williams, D., \& Mohammed, S. (2009). Discrimination and racial disparities in health: Evidence and needed research. Journal of Behavioral Medicine, 32(1): 20- 58. https://doi.org/10.1007/s10865$\underline{008-9185-0}$

Zaff, J. F., Kawashima-Ginsberg, K., Lin, E. S., Lamb, M., Balsano, A, \& Lerner, R. M. (2011). Developmental trajectories of civic engagement across adolescence: Disaggregation of an integrated construct. Journal of Adolescence, 34, 1207-1220. https://doi.org/10.1016/j.adolescence.2011.07.005 